\title{
Assessing Passenger Attitudes and Perception towards Service Quality of Egypt Air In-Flight Services by Using Satisfaction Measure
}

\author{
Ahmed Mahmoud Mohamed Ali \\ ${ }^{\text {a }}$ Hotel Management Department, \\ Faculty of Tourism and Hotels \\ Minia University
}

\begin{abstract}
Perception and attitudes towards airlines is an interesting subject for people travelling regularly, or not so regularly, by air. The subject is frequently discussed, and often one discovers that the discussion partner has some peculiar view on the topic. This makes one wonder about the average passenger's opinion. This research looks at passengers' Attitudes and perceptions towards Service Quality of Egypt Air In-Flight Services by Using Satisfaction Measure.
\end{abstract}

The numbers of airline companies increases as aviation develops. Airway companies should pay more attention to in-flight service quality to be able to earn passengers' loyalty and attract more passengers. For this reason, Egypt Air in-flight service should determine requests and needs of passengers and improve production and service in this direction. According to this, this research's purpose is to determine the effects of in-flight service quality on passengers. In this context, demographical characteristics of passengers, distribution percentages and frequencies of research area, dimensions related to in-flight service were determined and relations between these dimensions were evaluated and related results were tried to be determined.

To achieve that, this research employed a method of descriptive analytical methodology by using a questionnaire tool. The sample was passengers in Egyptair. 250 questionnaires were administered; only (200) returned questionnaires were valid for the statistical manipulation of data with a response rate of $80 \%$ from the total distributed questionnaires in Cairo international airport and Egyptair domestic sales offices. The results of the tools were analyzed using descriptive statistics, reliability analysis, and coefficient analysis, with the support of SPSS25.0.

The findings of this research will help Egypt Air to redefine their marketing strategy to one that is passengers-focused and emphasizes on Egypt Air InFlight Services quality The research thus recommended that airline managers should improve on the quality of service rendered to passengers since it is one of the determinants of the airline image and the airline image also determines the passengers' choice of repeat patronage. 
KEYWORDS: Attitudes, Perception, Service Quality, Satisfaction Measure, Egypt Air In-Flight Services

\section{Introduction}

The airline service quality is gaining interest from researchers. The airline manufacturing not only plays a vital role in the service industry but also contributes to other industries by transporting travelers to their required places all over the world (Rhoades and Waguespack, 2008). The airline industry has seen an average increase of about 12 percent per annum since the 1960s (Chau and Kao, 2009). In spite of the current decelerate due to a growing industry, deregulation and general crises, the world passenger traffic is anticipated to develop. In 2017, global air traffic passenger call for increasing by 7.5 percent on the year before. By 2018, traffic is projected to develop with other six percent (Statista, 2018). Among many elements that have influenced the traveler growth, airline service quality plays a vital role in the achievement of the airline industry. Airline Service quality promotes passenger delight, which translates directly into profitability, market share, and return on funding. Airline agencies are continuously search for ways to expand their competitiveness in airline service quality because of the agile business environment on account of extended competition (Ku and Fan, 2009). Consequently, an astute understanding of service quality in the airline industry can be valuable to service suppliers.

\section{Literature Review}

\section{The Concept of Service Quality}

Thai (2015) defined Quality as uniformity with fixed stipulations. This definition agrees with Ali et al. (2016) as he defined Quality as anything that work in with the traits of the product to meet the outer customers' needs. As well as, the product quality varies from that of a service as the former is tangible, whereas the latter is intangible. The American Society for Marketing, for instance, defines service as activities or advantages that are presented for sale or that are offered for being associated to a specific product. Kotler (2003), defined service as any behavior or performance based on an agreement between two parties: the supplier and the receiver, and the essence of this complementary procedure in intangible. Huseyin et al. (2005) defined service as a set of financial activities that provide time, location form and mental advantages. Beer (2003) defined service as a set of traits and overall properties of the service which intend to meet the customers' needs. Thai (2015) defined service as a set of traits that meet the customers' needs, reinforce the links between the institution and them, and upgrade the clients' value as well. 


\section{Service Quality Metrics:}

Four models have been recognized to evaluate the quality of the service; these models are particularly based on a set of evaluative pointers which can be adjustable or modified by a sort of service.

\section{Measuring Service Quality (SERVQUAL)}

The SERVQUAL model is a summarized multiple-item scale with reliability and validity that can be utilized to recognize and explain customers' perceptions as well as expectations of services which then improve the service quality and increase customer satisfaction (Parasuraman et al., 1988). Within the airline context, SERVQUAL has been utilized by various researchers to measure the effects of service quality (Sultan and Simpson, 2000; Shanka, 2012). Also, as suggested by (Hoang and Mai, 2013), SERVQUAL can be utilized flexibly in different types of industries. SERVQUAL used for service quality dimensions which is then adapted or modified to fit the typical features making up that particular company. In this research, apart from five SERVQUAL dimensions being used (tangibles, reliability, responsiveness, assurance and empathy), three more aspects are added to assist and meet with the purpose of this research as well as fitting with the distinctive characteristics of an airline industry. The ones being examined are the following dimensions: on-ground services, tangibles, reliability, responsiveness, assurance, empathy, safety records and image.

Parasuraman et al. (1988) has developed the new refined instrument of SERVQUAL with five dimensions:

Tangibility: physical facilities, equipment, and appearance of personnel.

Reliability: ability to perform the promised service dependably and accurately.

Responsiveness: willingness to help customers and provide prompt service.

Assurance: knowledge and courtesy of staff and their ability to inspire trust.

Empathy: caring individualized attention the company provides to its customers.

These five SERVQUAL dimensions are utilized to measure the gap between customers' perceptions for excellence and their perception of actual service delivered. The SERVQUAL model, when applied helps service providers to understand both customer expectations, and areas in need of quality Improvements. 
Figure1. Model of Service Quality Gaps

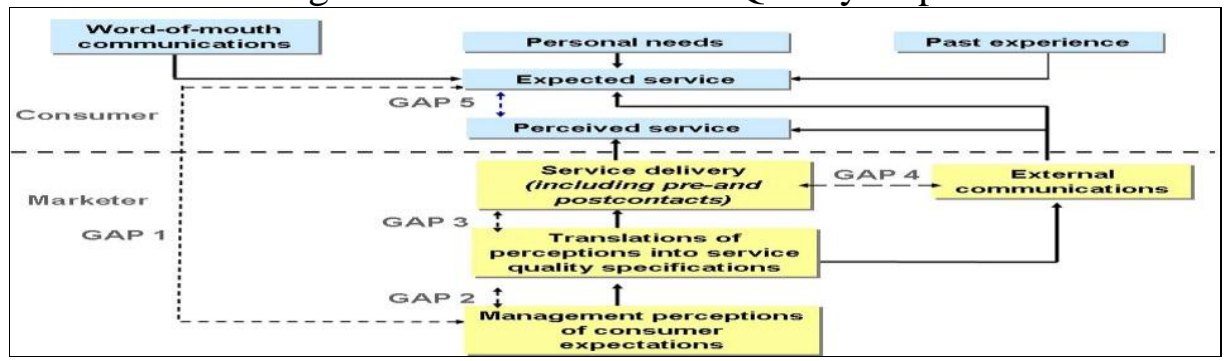

Source: Parasuraman et al. (1988).

\section{Satisfaction Measure:}

This measure is based totally on the Likert scale, which categorizes the customer's imaginative of quality of service into three, four, five or seven ranges, ranging from absolute quality to absolute quality, to quality of service in terms of significance to clients. Records about client's feelings about their services, whether positive or negative, which enables them make the vital decisions to enhance their endeavors (Abdel Mohsen, 2004)

\section{Counting Complaints Measure:}

The measure of number of complaints depends on the number and classification of complaints during a given period. This scale is simple to use, and it permits you to know how well clients wait for the fine of the service given. Moreover, knowledge of services that were not accepted by customers, and maybe the result of proper proposals those are applicable for development (Abdel Mohsen, 2004).

\section{Service Performance "SERVPERF"}

Gronin and Taylor (1992) supposed that this measure is used to measure the quality of the service, which emerged during the nineteen nineties, and the real performance measure centers on the opportunity of judging the quality of service by evaluating client trends towards the real performance level of the service and the strategies and levels of its submission (Hassan, 2004).

\section{Airline Hospitality and Attitude}

Based on past literature, the host personnel' performance or quality of hostguest linkage plays a vital role in the client's recognition and assessment of service (Berry, 2000; Nguyen, 2006; Gursoy et al., 2005; Han, Hyun and Kim, 2014; Li et al. 2016; Suess and Mody, 2017). That is, a host worker who is offered suitable behavior and method of treatment towards their visitor such as respectfulness, usefulness and friendliness is likely to encourage the visitor's favorable approach and satisfaction (Kim et al. 2016). Han et al. (2014) for example stated that excellence service performance significantly has an effect on airline passenger's beneficial attitude and their nice assessment of air travel experiences. Ahn et al. (2017) also claimed that cabin team's service performance can reinforce passengers' recognition of airline services and their overall experience with the flight. Impolite or 
inattentive workers' performance may inspire the client to share their unlikeable experience with others such as through posting a bad service reviews on company website, terminate their buy with the service vendors in addition to switch to different service providers ( $\mathrm{Li}$ et al. 2016). Particularly, in an airline hospitality study, it was mentioned that the cabin crew's attitude and manner of treatment have an influence on travellers' comfortable, calming and pleasant experience on the flight (Nameghi, 2013a). In other words, it is deduced in this research that travelers who perceive that the cabin crew is welcoming through making eye contact when communicating with them, spending time with them and wishing them a pleasant farewell when they are about leaving the plane will perceive their travelling experience with the airline as being relaxing, fun and enjoyable.

Teng and Chang (2013) and Ariffin and Maghzi (2012) stated that the suitable hosting quality can cultivate the guest's mental comfort via hostvisitor relations, which in turn develops guests' good affective responses or precise impact. Therefore, it is believed that a visitor who perceived that the host worker was being hospitable through showing real smile, emotions of generosity and being gracious will regard their service experience as being pleasant, respected and remarkable. Based on the review of literature, it is thus proposed that good assessment of the hospitality ends in positive attitudes towards the airline.

\section{Food and Beverage Service Quality in Egypt Air In-Flight Services}

While food and beverage service organizations are being held in specific classifications, airline catering organizations offer food and beverage to be served for the duration of the flights (Aktaş, 2001). 'Catering' means 'serving and providing food and beverages' as a Word (Sezgin and Özkaya, 2014). Airline catering organizations which can be based to meet nutrition needs of clients are very complicated organizations. These organizations work from taking orders to preparing and delivering (Zahari, Salleh, Kamaruddin and Katut, 2011; Rutkowska and Czarniecka-Skubina, 2015). If we consider a worldwide airline catering agency as an example, hundreds of arrivals and departures, which can be consisting of hundreds of staff working to serve food for thousands of travelers, are being made. All of these evidently reasons complexity (Jones, 2004). King (2001) depicted airline catering service as a high yields line of business. Airline catering services offer food and beverage for more than one million travellers and as a way to do this, they prepare and make their plans properly in spacious kitchens.

Quality of service can be expressed as attitudes and behaviors that may happen after utilization of the item and service and performance assessment during a longtime (Hoffman and Bateson, 1997). When evaluating performance, empathy, security, comfort and courtesy are evaluated (Tsaur, 
Chang and Yen, 2002). Customers who use goods and services make comparisons with other agencies and, if they get contented, they purchase it again. Therefore, developing quality of service is essential for organizations as it makes a great image perception, growing the loyalty, repurchasing and suggestions (Kozak, Özel and Karagöz Yüncü, 2011; Küçükergin, 2012). Menu planning, acquirement, food safety (hygiene and sanitation), application of cooking procedures, loading and adjusting are vital elements influencing the quality of service in airlines.

\section{Table 1: Factors influencing In-flight services quality}

\begin{tabular}{|c|c|}
\hline $\begin{array}{ll}\text { In } & \text { flight } \\
\text { services } & \end{array}$ & $\begin{array}{l}\text { a) Cabins crew service } \\
\text { - Attentiveness of service } \\
\text { - Courtesy toward passengers } \\
\text { - Welcoming of staff } \\
\text { - Performance and Professionalism } \\
\text { - Willingness to "provide" service } \\
\text { b) Food Quality } \\
\text { - Fine and Quantity of foods } \\
\text { - Consistency of meal standard } \\
\text { c) Air plane Characteristics } \\
\text { - Seat and width pitch } \\
\text { - Modem searching tools } \\
\text { - Cabin comfort and attraction }\end{array}$ \\
\hline
\end{tabular}

Source: Adopted by the Authors based on Khatib, F. (1998) An Investigation of Airline Service Quality, Passenger Satisfaction and Loyalty: The Case of Royal Jordanian Airline.

\section{Passengers' Satisfaction}

Customer is the secret to success for each agency and each economical commercial activity. Successful company popularity is based on that company long term relations with clients. Customer satisfaction as a personal perspective which is resulted from chronic comparisons between agency real performance and customer expected performance (Kisang and Han, 2008). Offering high quality and stabilized services is one solution for airlines service to draw travellers' satisfaction. Researches shown that airline service quality affect passengers' satisfaction and as a result on their buying. Airline Service quality and traveller's satisfaction is correlated ( Meysam and Ghasemali, 2016).

Traveller satisfaction in airline service operations thus has become essential for sustainable operation. To upgrade passenger satisfaction, airline service quality has got more attention (Dennett et al., 2000). To this regard, service quality is considered as a vital component of competitiveness by improving 
traveller satisfaction. Thus, providing recognized service quality and high traveller satisfaction is the essential matter and challenge confronting the airlines service industry particularly. Passenger satisfaction is the degree to which a service meets or exceeds passenger expectations. Satisfaction is an overall passenger manner towards a service presenter to the difference between what travellers wish and what they receive. When passengers are contented, they are more possible to return, for example some services in the nature are very complicated and include numerous levels for achieving passenger satisfaction (Han and Ryu, 2009). Archana and Subha (2012) have presented airline service quality elements containing service while flight, virtual services and office operation airline which can be notably prophesy passengers' satisfaction and satisfaction can influence faithfulness and the airline office popularity. Similarly, Abdolah et al. (2007) said that there is a definite relationship between satisfactions and make use of airlines in future in addition to the opportunity of offering it to others. Thus, passengers' satisfaction in airplane industry plays a vital role in scaling airline service quality and preserving their keeping with service vendors (Archana, and Subha, 2012; Lau et al, 2011; Abdolah et al, 2007).

\section{Airline Service Quality and Passengers' Satisfaction}

Numerous researches that have focused on a relationship between satisfaction and quality argued for distinct reviews in terms of relationship. Some opinions think that quality leads to satisfaction, Negi (2009) and others think that satisfaction leads to quality (Cronin and Taylor, 1992). Some studies indicate that quality and satisfaction are decided by the same features; like Parasurman et al., (1988) tried to interrelate passenger satisfaction to airline service quality. Negi (2009) clearly points out that overall airline service quality is notably related and contributes to the overall satisfaction of travelers. Passenger satisfaction is based on the level of airline service quality conveyed by the service providers (Saravanan \& Rao, 2007). Parasuraman et al. (1985) argued that when perceived service quality is high, then it will increase traveller satisfaction.

Airlines that are constantly fulfill their travellers' pleasure better retention degrees and higher profitability because of increasing passengers' satisfaction (Wicks and Roethlein, 2009). It is essential to keep travelers contented by trying to know their expectations of services introduced by service providers. In this way, airline service quality could be evaluated and thereby evaluating passenger satisfaction.

\section{RESEARCH METHODOLOGY}

This research follows the survey research methodology. Previous studies in Passenger Attitudes and Perception towards Service Quality of EgyptAir InFlight Services are included in this research paper. A questionnaire was designed to study the Satisfaction measure for measuring Attitudes and 
Perception towards Service Quality of EgyptAir In-Flight Services and its effect on passenger satisfaction. The questionnaire was applied to 200 passengers of Egypt air with a minimum age of 18 years. The data was collected by using structured questionnaire and convenience sampling. Then it was analyzed with Percentage Method, Frequencies, Mean, Standard Deviation and Reliability Analysis. Charts and tables are also included in this research.

\section{Data collection}

Data has been collected through questionnaires which were prepared in a way that is relevant to the situation so as to decrease invalid responses. They were distributed to passengers at Cairo international airport and domestic sales office.

\section{Measures}

This research's purpose is to determine the effects of in-flight service quality on passengers Attitudes and Perception towards Service Quality of EgyptAir In-Flight Services. To achieve that, this research employed a method of descriptive analytical methodology by using a questionnaire tool, a survey consisted of six sections was used as a data collection tool. The first section includes the demographic characteristics of respondents (gender, age group, educational level, Income, and main reason to fly). The second section included 7 variables Egyptair in-flight services. The third section included 6 variables representing Egyptair in-flight services employees. The fourth section included 39 variables representing Passengers' Food Beverage Preference. The fifth section included 9 variables representing Egyptair Cabin staff service. The sixth section included 7 variables representing Egyptair in-flight services passenger satisfaction. The questionnaire items were anchored according to the Five-Point Likert Scale, "1 = Strongly Disagree (SD)", "2 = Disagree (D)", "3 = Neutral (N)", "4 = Agree (A)", and " $5=$ Strongly Agree (SA)".

\section{Data Analysis}

The survey questionnaire data was encoded to SPSS (version 25.0). SPSS (version 25.0) was used to analyze the preliminary data, including Descriptive analysis, Reliability analysis.

\section{Results and Discussion}

The following part explains the results concerning the five dimensions representing the airline service quality delivered by Egypt Air. It aims to highlight the passengers' perception flying with Egypt Air.

\section{Sample characteristics}

The research covered a total of 200 out of 250 passengers completed the questionnaire in the 30 days survey period representing a response rate of 80 
$\%$. The results of this research have been organized according to the variables.

\section{Reliability analysis}

Before proceeding with further analysis, the reliability testing was leaded in order to ensure consistent measurement across various items in the questionnaire. Indeed, the reliability of a measure indicates stability and consistency of the instrument. Consequently, this method determines reliability through examining the internal consistency of the research instrument such as questions (items) in the questionnaire, which are normally presented. Cronbach's Alpha is one of the most frequently applied metrics to measure a scale's reliability, in which its index ranges from 0.0 to 1.0. Researchers should target a value closer to 1.0, as Alpha value proves that the instrument of the study is strong and consistent. However, it's important to note that in social sciences the threshold value of 0.7 is considered acceptable

Table 2: Cronbach's Alpha Value for Passenger Attitudes and Perception towards Service Quality of Egypt Air In-Flight Services

\begin{tabular}{|c|c|c|c|}
\hline Variables & $\begin{array}{l}\text { No. of } \\
\text { items }\end{array}$ & $\begin{array}{l}\text { Cronbach's } \\
\text { Alpha Value }\end{array}$ & $\begin{array}{c}\text { Validity } \\
\text { Coefficient * }\end{array}$ \\
\hline Egyptair in-flight services & 7 & 0.829 & 0.910 \\
\hline $\begin{array}{l}\text { Egyptair in-flight services } \\
\text { employees }\end{array}$ & 6 & 0.810 & 0.90 \\
\hline $\begin{array}{lcc}\text { Passengers' } & \text { Food } & \text { Beverage } \\
\text { Preference } & & \end{array}$ & 39 & 0.882 & 0.939 \\
\hline Egyptair Cabin staff service & 9 & 0.755 & 0.869 \\
\hline $\begin{array}{l}\text { Egyptair in-flight services } \\
\text { passenger satisfaction }\end{array}$ & 7 & 0.890 & 0.943 \\
\hline Total & 68 & 0.855 & 0.925 \\
\hline
\end{tabular}

* Validity coefficient $=\sqrt{\text { Reliability coefficient }}$

In order to measure the internal consistency and reliability of the study's constructs. Cronbach's Alpha $(\alpha)$ measure was used. The scales' reliabilities were measured and the Cronbach's Alpha of all scales in Table (2) ranged from 0.755 to 0.890 , and for total questionnaire items was (0.855), this indicate an acceptable Cronbach's Alpha value for each field, whenever Cronbach's Alpha value is acceptable if it's more than (0.7). It is also evident that the validity coefficient is $(92.5 \%)$ which means the reliability and validity of the study sample.

\section{Descriptive analysis}

Descriptive statistics frequency and percentage, histogram and tabular summarizations were used to present demographic factors, independent variables and for the level of Egyptair in-flight services passenger satisfaction. 
Table3: Distribution of the Passengers Participating in the Survey according to Socio-Demographic Characteristics

\begin{tabular}{|c|c|c|c|}
\hline \multicolumn{2}{|c|}{ Descriptive Features } & Frequency & $\begin{array}{c}\text { Percentage } \\
(\%)\end{array}$ \\
\hline \multicolumn{4}{|l|}{ Age groups } \\
\hline & $18-28$ & 30 & 15 \\
\hline & $29-39$ & 90 & 45 \\
\hline & $40-50$ & 10 & 5 \\
\hline & $51-59$ & 50 & 25 \\
\hline & 60 and above & 20 & 10 \\
\hline \multicolumn{4}{|l|}{ Gender } \\
\hline & Male & 128 & 64 \\
\hline & Female & 72 & 36 \\
\hline \multicolumn{4}{|l|}{ Education level } \\
\hline & Bachelor Degree & 100 & 50 \\
\hline & Diploma & 10 & 5 \\
\hline & Master Degree & 60 & 30 \\
\hline & PHD degree & 30 & 15 \\
\hline \multicolumn{4}{|c|}{ Income (per month: in Egyptian pound) } \\
\hline & Less than 1.000 & 0 & 0 \\
\hline & $1.000-2.999$ & 18 & 9 \\
\hline & $3.000-5.999$ & 104 & 52 \\
\hline & $6.000-8.999$ & 35 & 17.5 \\
\hline & 9.000 and above & 43 & 21.5 \\
\hline \multicolumn{4}{|l|}{ main reason to fly } \\
\hline & Business & 60 & 30 \\
\hline & Leisure & 100 & 50 \\
\hline & $\begin{array}{l}\text { Personal reasons / } \\
\text { Commuting }\end{array}$ & 40 & 20 \\
\hline
\end{tabular}

Table (3) shows the discussion of the research findings begins with a brief demographic profile of respondents in terms of gender, age, education level, income, and main reason to fly. $64 \%$ of the respondents were male whereas $36 \%$ of them were female. Most of the respondents $45 \%$ were aged between 29 and 39 years. Regarding the education level, $50 \%$ of the respondents were studying for Bachelor' degrees. Additionally, more than $52 \%$ of the respondents reported an income range between 3.000and 5.999 EGP. Regarding the purpose of their journeys, about 50\% mentioned that they were travelling for leisure. 
Table 4: Mean Rating and percentages the respondents' of Egyptair inflight services

\begin{tabular}{|l|c|c|c|c|}
\hline \multicolumn{1}{|c|}{ Variables } & Mean & SD & Rank & Attitude \\
\hline Aircraft is a safe and clean & $\mathbf{3 . 5 6}$ & $\mathbf{0 . 8 6 8}$ & $\mathbf{5}$ & Agree \\
\hline $\begin{array}{l}\text { Quality of catering served in } \\
\text { plane is good }\end{array}$ & $\mathbf{4 . 2 0}$ & $\mathbf{0 . 7 1 0}$ & $\mathbf{1}$ & $\begin{array}{c}\text { Completely } \\
\text { agree }\end{array}$ \\
\hline Plane toilets are clean & $\mathbf{3 . 8 7}$ & $\mathbf{0 . 8 1 2}$ & $\mathbf{3}$ & Agree \\
\hline Plane seats are clean & $\mathbf{4 . 0 5}$ & $\mathbf{0 . 7 5 5}$ & $\mathbf{2}$ & Agree \\
\hline Plane seats are comfortable & $\mathbf{3 . 6 7}$ & $\mathbf{0 . 8 0 4}$ & $\mathbf{4}$ & Agree \\
\hline $\begin{array}{l}\text { Quality of air-conditioning in the } \\
\text { planes are good }\end{array}$ & $\mathbf{3 . 5 0}$ & $\mathbf{0 . 8 5 5}$ & $\mathbf{6}$ & Agree \\
\hline $\begin{array}{l}\text { Up to date newspapers, } \\
\text { magazines and video films are } \\
\text { available during the flight }\end{array}$ & $\mathbf{3 . 1 9}$ & $\mathbf{0 . 9 7 9}$ & $\mathbf{7}$ & Neutral \\
\hline
\end{tabular}

The detailed examination of the results presented in Table (5) reveals the respondents' responses pertaining to Egyptair in-flight services. The average score resulted with a mean of 3.72. This indicates that majority of the cases tend to mark on the high of the scale on a 1 to 5 range. However, most of the items resulted with a slightly higher mean than 3 indicating the agreeableness of the respondents on those items, as imperative for to Egyptair in-flight services.

The highest mean values for Airline service emerged for the item "Quality of catering served in plane is good" (mean $=4.20$ ), followed by "Plane seats are clean" (mean $=4.05)$, whereas, the lowest mean value for this construct is for "Up to date newspapers, magazines and video films are available during the flight, followed by "Quality of air-conditioning in the planes are good"

Table 5: Mean Rating and percentages the respondents' of Egyptair inflight services employees

\begin{tabular}{|l|c|c|c|c|}
\hline \multicolumn{1}{|c|}{ Variables } & Mean & $\begin{array}{c}\text { Std } \\
\text { deviation }\end{array}$ & Rank & Attitude \\
\hline $\begin{array}{l}\text { Staffs' general attitude is } \\
\text { good }\end{array}$ & $\mathbf{3 . 8 7}$ & $\mathbf{0 . 5 9 0}$ & $\mathbf{3}$ & Agree \\
\hline $\begin{array}{l}\text { Airline staff give exact answers to } \\
\text { your questions }\end{array}$ & $\mathbf{4 . 1 4}$ & $\mathbf{0 . 5 2 0}$ & $\mathbf{1}$ & Agree \\
\hline $\begin{array}{l}\text { staff show personal care equally to } \\
\text { everyone }\end{array}$ & $\mathbf{4 . 1 2}$ & $\mathbf{0 . 5 4 0}$ & $\mathbf{2}$ & Agree \\
\hline $\begin{array}{l}\text { staff have the knowledge to answer } \\
\text { your questions }\end{array}$ & $\mathbf{3 . 1 9}$ & $\mathbf{0 . 6 5 0}$ & $\mathbf{5}$ & Neutral \\
\hline The airline staff show empathy & $\mathbf{3 . 5 2}$ & $\mathbf{0 . 6 9 0}$ & $\mathbf{4}$ & Agree \\
\hline Airline staff are aware of their duties & $\mathbf{3 . 1 2}$ & $\mathbf{0 . 7 9 0}$ & $\mathbf{6}$ & Neutral \\
\hline
\end{tabular}


Table (5) presents the means and standard deviations of Egypt Air in-flight services employees, where the means ranged between (4.14-3.12), compared with the total instrument mean for the domain (3.66) the item "Airline staff give exact answers to your questions" ranked first with a mean and standard deviation $($ mean $=4.14$, standard deviation $=0.520)$ compared with the total instrument mean and the standard deviation. The item "Airline staff are aware of their duties" ranked last reached a mean (3.12) and the standard deviation was (0.790) compared with the mean and standard deviation of the total instrument.

Table 6: Mean Rating and percentages of the respondents' of

Passengers' Food and Beverage Preference

\begin{tabular}{|c|c|c|c|c|}
\hline Variables & Mean & $\begin{array}{c}\text { Std } \\
\text { deviation }\end{array}$ & Rank & Attitude \\
\hline \multicolumn{5}{|l|}{ Nutrition } \\
\hline $\begin{array}{l}\text { Satisfaction of the items on the } \\
\text { menu }\end{array}$ & 2.87 & 0.990 & 4 & Neutral \\
\hline $\begin{array}{l}\text { Foods being high in nutritional } \\
\text { value }\end{array}$ & 3.04 & 0.920 & 2 & Neutral \\
\hline $\begin{array}{l}\text { The raw materials utilized in food } \\
\text { production are fresh and organic }\end{array}$ & 3.22 & 0.960 & 1 & Neutral \\
\hline $\begin{array}{l}\text { Food and beverages have a good } \\
\text { taste. }\end{array}$ & 2.89 & 0.950 & 3 & Neutral \\
\hline $\begin{array}{l}\text { Food and beverages are suitable for } \\
\text { the target groups and eating habits. }\end{array}$ & 2.72 & 0.990 & 5 & Neutral \\
\hline \multicolumn{5}{|l|}{ Service } \\
\hline $\begin{array}{l}\text { Staff serving food and beverages in } \\
\text { the right way. }\end{array}$ & 2.87 & $\mathbf{0 . 8 9 0}$ & 5 & Neutral \\
\hline $\begin{array}{l}\text { Staff serving food and beverages on } \\
\text { the right time. }\end{array}$ & 3.04 & 0.720 & 2 & Neutral \\
\hline Staffs was friendly with passengers & 3.22 & 0.460 & $\mathbf{1}$ & Neutral \\
\hline $\begin{array}{l}\text { Staffs have ability to solve } \\
\text { passenger's problems. }\end{array}$ & 2.89 & 0.650 & 3 & Neutral \\
\hline $\begin{array}{l}\text { Staffs have a good knowledge and } \\
\text { skill level toward food and } \\
\text { beverage consumption. }\end{array}$ & 2.72 & 0.790 & 6 & Neutral \\
\hline $\begin{array}{l}\text { Staff serving food and beverages } \\
\text { according } \\
\text { standards. }\end{array}$ & 2.62 & 0.690 & 7 & Neutral \\
\hline $\begin{array}{l}\text { The passengers were motivated } \\
\text { with food and beverages flavor. }\end{array}$ & 2.58 & 0.590 & 8 & Disagree \\
\hline Food and beverages having a good & 2.87 & $\mathbf{0 . 5 9 0}$ & 4 & Neutral \\
\hline
\end{tabular}




\begin{tabular}{|c|c|c|c|c|}
\hline \multirow{2}{*}{\multicolumn{5}{|c|}{$\begin{array}{l}\text { decoration. } \\
\text { Hvoiene and Sanitation }\end{array}$}} \\
\hline & & & & \\
\hline $\begin{array}{l}\text { The service tools' being well- } \\
\text { presented. }\end{array}$ & 2.87 & 0.790 & 4 & Neutral \\
\hline $\begin{array}{l}\text { The portable dining table's being } \\
\text { well-presented. }\end{array}$ & 3.04 & 0.820 & 2 & Neutral \\
\hline $\begin{array}{l}\text { The service staff's implementing } \\
\text { personnel hygiene. }\end{array}$ & 3.22 & 0.660 & 1 & Neutral \\
\hline $\begin{array}{l}\text { Passengers believe that Egypt Air } \\
\text { company implemented production } \\
\text { hygiene and sanitation rules. }\end{array}$ & 2.89 & 0.750 & 3 & Neutral \\
\hline \multicolumn{5}{|l|}{ Beverages } \\
\hline $\begin{array}{l}\text { Beverages served at the appropriate } \\
\text { temperature. }\end{array}$ & 2.87 & 0.990 & 4 & Neutral \\
\hline $\begin{array}{l}\text { The variety of alcoholic beverages' } \\
\text { being sufficient. }\end{array}$ & 3.04 & 0.520 & 2 & Neutral \\
\hline $\begin{array}{l}\text { The variety of soft drink being } \\
\text { sufficient. }\end{array}$ & 3.22 & 0.660 & 1 & Neutral \\
\hline $\begin{array}{l}\text { Beverages served in appropriate } \\
\text { glasses. }\end{array}$ & 2.89 & 0.757 & 3 & Neutral \\
\hline \multicolumn{5}{|l|}{ Menu Planning } \\
\hline $\begin{array}{l}\text { The variety of low calories food } \\
\text { items on the menu }\end{array}$ & 2.87 & 0.890 & 4 & Neutral \\
\hline $\begin{array}{l}\text { The variety of vegetarian food } \\
\text { items on the menu }\end{array}$ & 3.04 & 0.720 & 2 & Neutral \\
\hline $\begin{array}{l}\text { The variety of special and regional } \\
\text { dishes on the menu }\end{array}$ & 3.22 & 0.660 & 1 & Neutral \\
\hline $\begin{array}{l}\text { The variety of food which is } \\
\text { suitable for children on the menu }\end{array}$ & 2.89 & 0.600 & 3 & Neutral \\
\hline $\begin{array}{l}\text { Egypt Air considered religious } \\
\text { precision when planning the menu }\end{array}$ & 2.72 & 0.690 & 6 & Neutral \\
\hline $\begin{array}{l}\text { Menu items is easy to read and } \\
\text { understandable }\end{array}$ & 2.62 & 0.690 & 7 & Neutral \\
\hline $\begin{array}{l}\text { Menu items contain detailed } \\
\text { information of the food and its } \\
\text { contents. }\end{array}$ & 2.58 & 0.490 & 8 & Disagree \\
\hline $\begin{array}{l}\text { Better implementation of menu } \\
\text { planning rules compared to other } \\
\text { airlines }\end{array}$ & 2.87 & 0.790 & 5 & Neutral \\
\hline
\end{tabular}




\begin{tabular}{|c|c|c|c|c|}
\hline \multicolumn{5}{|l|}{ Complementary Services } \\
\hline $\begin{array}{l}\text { Service tools being used in } \\
\text { accordance with service standards. }\end{array}$ & 2.87 & 0.590 & 3 & Neutral \\
\hline $\begin{array}{l}\text { Positioning of serving utensils such } \\
\text { as (forks, knives, plates, etc.) } \\
\text { according to international } \\
\text { standards. }\end{array}$ & 3.04 & 0.720 & 2 & Neutral \\
\hline $\begin{array}{l}\text { Using innovative and conceptual } \\
\text { designs in dining sets. }\end{array}$ & 3.22 & 0.460 & 1 & Neutral \\
\hline \multicolumn{5}{|l|}{ Employee } \\
\hline $\begin{array}{l}\text { Egypt Air has professional food and } \\
\text { beverage staff. }\end{array}$ & 2.87 & 0.590 & 4 & Neutral \\
\hline $\begin{array}{l}\text { The quality of staff service's } \\
\text { making passengers feel special. }\end{array}$ & 3.04 & 0.720 & 2 & Neutral \\
\hline $\begin{array}{l}\text { Staff Prepared foods with } \\
\text { traditional production. }\end{array}$ & 3.22 & 0.460 & 1 & Neutral \\
\hline $\begin{array}{l}\text { Staff Reflection of ethnic/local } \\
\text { ambience during the presentation. }\end{array}$ & 2.89 & 0.650 & 3 & Neutral \\
\hline \multicolumn{5}{|l|}{ Prices } \\
\hline $\begin{array}{l}\text { Sufficient amount of services } \\
\text { portion according to prices. }\end{array}$ & 2.87 & 0.590 & 3 & Neutral \\
\hline $\begin{array}{l}\text { Including food and beverage } \\
\text { service in ticket prices. }\end{array}$ & 3.04 & 0.720 & 2 & Neutral \\
\hline $\begin{array}{l}\text { Keeping corporate image } \\
\text { foreground instead of sold ticket } \\
\text { prices. }\end{array}$ & 3.22 & 0.460 & 1 & Neutral \\
\hline
\end{tabular}

Table (6) shows the means and standard deviations of the respondents' of Passengers' Food and Beverage Preference with regard to nutrition variable, where the means ranged between (3.22-2.72), compared with the total instrument mean for the domain (3.66) the item "the raw materials utilized in food production are fresh and organic" ranked first with a mean and standard deviation $($ mean $=3.22$, standard deviation $=0.960)$ compared with the total instrument mean and the standard deviation. The item "food and beverages are suitable for the target groups and eating habits" ranked last reached with a mean (2.72) and the standard deviation was $(\mathbf{0 . 9 9 0})$ compared with the mean and standard deviation of the total instrument.

Means and standard deviations of the respondents' of Passengers' Food and Beverage Preference with regard to service variable, where the means ranged between (3.22-2.58), compared with the total instrument mean for the domain (3.66) the item "staffs was friendly with passengers" ranked first with a mean and standard deviation (mean $=3.22$, standard deviation $=0.460$ ) 
compared with the total instrument mean and the standard deviation. The item "the passengers were motivated with food and beverages flavor" ranked last reached with a mean (2.58) and the standard deviation was (0.590) compared with the mean and standard deviation of the total instrument.

Means and standard deviations of the respondents' of Passengers' Food and Beverage Preference with regard to hygiene and sanitation variable, where the means ranged between (3.22-2.87), compared with the total instrument mean for the domain (3.66) the item "the service staff's implementing personnel hygiene" ranked first with a mean and standard deviation $($ mean $=3.22$, standard deviation $=0.660)$ compared with the total instrument mean and the standard deviation. The item "the service tools' being well-presented" ranked last reached with a mean (2.87) and the standard deviation was (0.790) compared with the mean and standard deviation of the total instrument.

Means and standard deviations of the respondents' of Passengers' Food and Beverage Preference with regard to beverages variable, where the means ranged between (3.22-2.87), compared with the total instrument mean for the domain (3.66) the item "the variety of soft drink being sufficient." ranked first with a mean and standard deviation (mean=3.22, standard deviation $=0.660$ ) compared with the total instrument mean and the standard deviation. The item "beverages served at the appropriate temperature" ranked last reached with a mean (2.87) and the standard deviation was (0.990) compared with the mean and standard deviation of the total instrument.

Means and standard deviations of the respondents' of Passengers' Food and Beverage Preference with regard to menu planning variable, where the means ranged between (3.22-2.58), compared with the total instrument mean for the domain (3.66) the item "the variety of special and regional dishes on the menu" ranked first with a mean and standard deviation (mean $=3.22$, standard deviation $=0.660)$ compared with the total instrument mean and the standard deviation. The item "menu items contain detailed information of the food and its contents." ranked last reached with a mean (2.58) and the standard deviation was (0.490) compared with the mean and standard deviation of the total instrument.

Means and standard deviations of the respondents' of Passengers' Food and Beverage Preference with regard to complementary services variable, where the means ranged between (3.22-2.87), compared with the total instrument mean for the domain (3.66) the item "Using innovative and conceptual designs in dining sets" ranked first with a mean and standard deviation $($ mean $=3.22$, standard deviation $=0.460)$ compared with the total 
instrument mean and the standard deviation. The item "service tools being used in accordance with service standards" ranked last reached with a mean (2.87) and the standard deviation was (0.590) compared with the mean and standard deviation of the total instrument.

Means and standard deviations of the respondents' of Passengers' Food and Beverage Preference with regard to Employee variable, where the means ranged between (3.22-2.87), compared with the total instrument mean for the domain (3.66) the item "staff Prepared foods with traditional production" ranked first with a mean and standard deviation (mean=3.22, standard deviation $=0.460$ ) compared with the total instrument mean and the standard deviation. The item "Egypt Air has professional food and beverage staff" ranked last reached with a mean (2.87) and the standard deviation was (0.590) compared with the mean and standard deviation of the total instrument.

Means and standard deviations of the respondents' of Passengers' Food and Beverage Preference with regard to prices variable, where the means ranged between (3.22-2.87), compared with the total instrument mean for the domain (3.66) the item "keeping corporate image foreground instead of sold ticket prices" ranked first with a mean and standard deviation (mean=3.22, standard deviation $=0.460$ ) compared with the total instrument mean and the standard deviation. The item "sufficient amount of services portion according to prices" ranked last reached with a mean (2.87) and the standard deviation was (0.590) compared with the mean and standard deviation of the total instrument.

Table 7: Mean Rating and percentages the respondents' of Egyptair Cabin staff service

\begin{tabular}{|l|c|c|c|c|}
\hline Cabin staff service & Mean & $\begin{array}{c}\text { Std } \\
\text { deviation }\end{array}$ & Rank & Attitude \\
\hline $\begin{array}{l}\text { The cabin crew are very } \\
\text { courteous toward passengers }\end{array}$ & $\mathbf{3 . 1 1}$ & $\mathbf{0 . 9 8 0}$ & $\mathbf{9}$ & Neutral \\
\hline $\begin{array}{l}\text { Egypt air cabin crew give } \\
\text { passengers individual attention }\end{array}$ & $\mathbf{3 . 1 9}$ & $\mathbf{0 . 8 4 0}$ & $\mathbf{8}$ & Neutral \\
\hline $\begin{array}{l}\text { Cabin crew give prompt } \\
\text { service to passengers }\end{array}$ & $\mathbf{4 . 3 6}$ & $\mathbf{0 . 4 3 0}$ & $\mathbf{1}$ & $\begin{array}{l}\text { Completely } \\
\text { agree }\end{array}$ \\
\hline Cabin crew are willing to help & $\mathbf{3 . 5 4}$ & $\mathbf{0 . 7 6 0}$ & $\mathbf{7}$ & Agree \\
\hline $\begin{array}{l}\text { Cabin crew can speak foreign } \\
\text { languages }\end{array}$ & $\mathbf{3 . 5 7}$ & $\mathbf{0 . 7 2 0}$ & $\mathbf{6}$ & Agree \\
\hline Cabin crew show an awareness & $\mathbf{3 . 6 6}$ & $\mathbf{0 . 7 0 0}$ & $\mathbf{5}$ & Agree \\
\hline
\end{tabular}




\begin{tabular}{|l|c|c|c|c|}
\hline of different cultures & & & & \\
\hline $\begin{array}{l}\text { Cabin-crew have a smart } \\
\text { appearance }\end{array}$ & $\mathbf{4 . 1 4}$ & $\mathbf{0 . 4 5 0}$ & $\mathbf{2}$ & Agree \\
\hline Cabin announcements are clear & $\mathbf{3 . 9 4}$ & $\mathbf{0 . 4 5 9}$ & $\mathbf{3}$ & Agree \\
\hline $\begin{array}{l}\text { Egypt air offers appropriate } \\
\text { services for children }\end{array}$ & $\mathbf{3 . 8 4}$ & $\mathbf{0 . 6 4 0}$ & $\mathbf{4}$ & Agree \\
\hline
\end{tabular}

The detailed examination of the results presented in Table (7) reveals the respondents' responses pertaining to cabin crew. The average score resulted with a mean of 3.71. This indicates that majority of the cases tend to mark on the high of the scale on a 1 to 5 range. However, most of the items resulted with a slightly higher mean than 3 indicating the agreeableness of the respondents on those items, as imperative for Egyptair Cabin staff service. The highest mean values for Egyptair Cabin staff service emerged for the item "Cabin crew give prompt service to passengers" (mean $=4.36$ ), followed by "Cabin-crew have a smart appearance" (mean $=4.14)$, whereas, the lowest mean value for this construct is for "The cabin crew are very courteous toward passengers", followed by "Egypt air cabin crew give passengers individual attention".

Table 8: Mean Rating and percentages the respondents' of Egyptair inflight services passenger satisfaction

\begin{tabular}{|l|c|c|c|c|}
\hline \multicolumn{1}{|c|}{ Variables } & Mean & $\begin{array}{c}\text { Std } \\
\text { deviation }\end{array}$ & Rank & Attitude \\
\hline $\begin{array}{l}\text { Overall impression of Egyptair in-flight } \\
\text { services }\end{array}$ & $\mathbf{3 . 4 5}$ & $\mathbf{0 . 7 5 0}$ & $\mathbf{7}$ & Agree \\
\hline $\begin{array}{l}\text { Overall impression of catering service } \\
\text { quality }\end{array}$ & $\mathbf{3 . 8 0}$ & $\mathbf{0 . 7 3 7}$ & $\mathbf{2}$ & Agree \\
\hline $\begin{array}{l}\text { Overall impression of all services } \\
\text { offered by Egyptair in-flight services }\end{array}$ & $\mathbf{3 . 6 3}$ & $\mathbf{0 . 7 2 6}$ & $\mathbf{4}$ & agree \\
\hline $\begin{array}{l}\text { The next time I need to fly, I would } \\
\text { certainly fly with Egypt air }\end{array}$ & $\mathbf{3 . 5 5}$ & $\mathbf{0 . 7 6 7}$ & $\mathbf{5}$ & Agree \\
\hline $\begin{array}{l}\text { My choice of Egyptair in-flight } \\
\text { services as a service provider was a } \\
\text { wise one }\end{array}$ & $\mathbf{3 . 4 7}$ & $\mathbf{0 . 8 1 0}$ & $\mathbf{6}$ & Agree \\
\hline $\begin{array}{l}\text { I feel that my experience with } \\
\text { Egyptair in-flight services has been } \\
\text { enjoyable }\end{array}$ & $\mathbf{3 . 6 8}$ & $\mathbf{0 . 7 2 2}$ & $\mathbf{3}$ & Agree \\
\hline $\begin{array}{l}\text { I now have a more positive attitude } \\
\text { towards the Egyptair in-flight services }\end{array}$ & $\mathbf{4 . 0 3}$ & $\mathbf{0 . 6 3 7}$ & $\mathbf{1}$ & Agree \\
\hline
\end{tabular}

Table (8) presents the means and standard deviations of Egyptair in-flight services passenger satisfaction, where the means ranged between (4.03-3.47), compared with the total instrument mean for the domain (3.66) the item "I 
now have a more positive attitude towards the Egyptair in-flight services" ranked first with a mean and standard deviation (mean=4.03, standard deviation $=0.637$ ) compared with the total instrument mean and the standard deviation. The item "Overall impression of Egyptair in-flight services" ranked last reached a mean (3.45) and the standard deviation was (0.750) compared with the mean and standard deviation of the total instrument.

\section{Summary and Conclusion}

Perception and attitudes towards airlines is an interesting subject for passengers regularly, or not so regularly, by air. The subject is frequently discussed, and often one discovers that the discussion partner has some peculiar view on the topic. This makes one wonder about the average passenger's opinion. This research looks at passengers' Attitudes and perceptions towards Service Quality of Egypt Air In-Flight Services by Using Satisfaction Measure.

Satisfaction Measure has been used to determine service quality in Egypt Air in-flight services Because of being easy used-form and the reliability of Satisfaction Measure; it was preferred to use to determine Egypt air service quality as a sample from an area of inflight service. The research covered a total of 200 out of 250 passengers completed the questionnaire in the 30 days survey period representing a response rate of $80 \%$. The results of this research have been organized according to the variables. In order to measure the internal consistency and reliability of the study's constructs. Cronbach's Alpha $(\alpha)$ measure was used. The scales' reliabilities were measured and the Cronbach's Alpha of all scales ranged from 0.755 to 0.890 (acceptance).

Totally, it was seen that \%64 passengers were male and Most of the respondents $45 \%$ were aged between 29 and 39 years. Regarding the education level, $50 \%$ of the respondents were studying for Bachelor' degrees. Additionally, more than $52 \%$ of the respondents reported an income range between 3.000and 5.999 EGP. Regarding the purpose of their journeys, about $50 \%$ mentioned that they were travelling for leisure.

The most important results of the field study are shown below that Egypt air in-flight services passenger satisfaction, where the means ranged between (4.03-3.47), compared with the total instrument mean for the domain (3.66) the item "I now have a more positive attitude towards the Egyptair in-flight services" ranked first with a mean and standard deviation (mean=4.03, standard deviation $=0.637$ ) 


\section{Recommendations for Egyptair in- flight services}

1. Egypt Air in-flight service should improve the weaknesses in all quality service dimensions, particularly catering service. There are requirements for supporting high-tech equipment on board, training employees for supporting spontaneous care and concern for passengers.

2. Egypt Air in-flight service should improve strategies to improve in flight service quality across all the service quality dimensions in during a manner that suit the preferences of those market segments they select to serve.

3. Egypt Air in-flight service should recognize the changing requirements and expectations of air passengers; hence, passenger surveys should be periodically conducted to generate three types of service performance reports: monthly update, quarterly performance review, and an annual performance report.

4. Egypt Air in-flight service should customize their services offered by identifying unique service requirements of individual passengers, providing in-flight entertainment and variety in-flight meals, and more newspapers and magazines, Also, it is recommended that the variety of the programs must be increased according to male and female preferences, when flight entertainment programs are selected.

5. Egypt Air in-flight service managers should deliver services as secure and sometimes, when the services delivered fall short of expectations, effort should be made to immediately restore any service failure and sincere apologies should be offered to the passenger with a real commitment to stop the reoccurrence of such service hiccups.

\section{References}

- Abdullah, K., Manaf, N., and Noor, K. (2007). Measuring the Service Quality of Airline Services in Malaysia", IIUM Journal of Economics and Management, Vol. 15 No. 1, pp. 1-29.

- Ahn, Y.J., Kim, I., and Hyun, S.S. (2015). Critical In-flight and Ground-service Factors Influencing Brand Prestige and Relationship between Brand Prestige, Well-being Perceptions, and Brand Loyalty: First-class Passengers, Journal of Travel and Tourism Marketing, 32: S114-S138.

- Aktaş, A. (2001). Ağırlama Hizmet İşletmelerinde Yiyecek İçecek Yönetimi. Antalya: Livane Matbaası. 
- Ali F., Zhou Y., Hussain K., Kumat P., Neethiahnanthan N., Ragavan A., (2016). Quality Assurance in Education, Vol.24, No.1, pp.7-94. doi:http://dx.doi.org/10.1108/QAE-11- 2012-0046.

- Archana, R., and Subha, M. (2012). A Study on Service Quality and Passenger Satisfaction on Indian Airlines", International Journal of Multidisciplinary Research, Vol. 2 No. 2, pp. 50-63.

- Ariffin, A.A.M and Maghzi A. (2012). A preliminary Study on Customer Expectations of Hotel Hospitality: Influences of Personnel and Hotel Factors, International Journal of Hospitality Management, 31(1), 191-198.

- Beer, Michael, (2003). Why Total Quality Management Programs Do not Persist The role of Management Quality and Implication for Leading a TQM Transformation, Decision Science, Vol.34, No.4, pp. 624-642.

- Berry, L.L. (2000). Cultivating Service Brand Equity. Journal of the Academy of Marketing Science, 28(1), 128-137.

- Chau, V.S., and Kao, Y. (2009). Bridge over Troubled Water or Long and Winding road? Gap-5 in Airline Service Quality Performance Measures", Managing Service Quality, Vol. 19, No. (1), pp. 106-134.

- Cronin, J., and Taylor, S. (1992). Measuring Service Quality: A Reexamination and Extension, Journal of Marketing, 56 (July) pp.55-68.

- Dennet C., Ineson, M., Stone, J., and Colgate, M. (2000). PreBookable Services in the Chartered Airline Industry: Increasing Satisfaction through Differentiation.

- Grönroos, C. (1984). A service quality model and its marketing implications, European Journal of Marketing, Vol. (18), No. (4), pp. 36-44.

- Gursoy, D., Chen, M. and Kim, H.J. (2005). The US Airlines Relative Positioning Based on Attributes of Service Quality, Tourism Management, 26(1), 57-67.

- Han, H., and Ryu, K. (2009). The Roles of the Physical Environment, Price Perception, and Customer Satisfaction in Determining Customer Loyalty in the Restaurant Industry, Journal of Hospitality \& Tourism Research, Vol. 33 No. 4, pp. 487510. 
- Han, H., Hyun, S.S. and Kim, W. (2014). In-flight Service Performance and Passenger Loyalty: A Cross-National (China/Korea) Study of Travelers Using Low-cost Carriers, Journal of Travel \& Tourism Marketing, 31(5): 589-609.

- Hoang, A., and Mai, K. (2013). Direct and Indirect Effects of Customer Satisfaction Through Product and Service Quality-A Study of Phunhuan Jewelry Stores in Ho Chi Minh City, Vietnam, Journal of Economics, Business and Management, vol. 1.

- Hoffman, K.D. \& Bteson, J.E. (1997). Essentials of Service Marketing. USA: The Dryden Press. İnternational Civil Aviation Organization (ICAO) (2016). Product \& Services Catalogue. Web: http://www.icao.int/publications/catalogue/cat_2016_en.pdf, (Accessed Date: 20.02.2017).

- Huseyin, A., Salime,S. and Salih, T. (2005). Customer Service Quality in The Derek Cypriot Banking Industry, Managing Service Quality, Vol.15, No.1,pp 41-56.

- Jones, P. (2004). Flight Catering. Oxford: Elsevier.

- Khatib, F. (1998). An Investigation of Airline Service Quality, Passenger Satisfaction and Loyalty: The Case of Royal Jordanian Airline, PhD degree, Sheffield University Management School, Sheffield University.

- Kim, S., Kim, I., and Hyun, S.S. (2016). First-class In-flight Services and Advertising Effectiveness: Antecedents of CustomerCentric Innovativeness and Brand Loyalty in the United States (US) Airline Industry, Journal of Travel \& Tourism Marketing, 33(1): 118-140.

- King, T. (2001). In-flight Catering. Tourism And Hospitality research, 3(2), 181-184.

- Kisang, R., and Heesup, H. (2008). Influence of Physical Environment on (2008).

- Kotler, P. (2003). Management Marketing, New Jersey, United States of America, p. 415.

- Kozak, N., Özel, Ç. H. \& Karagöz Yüncü, D. (2011). Hizmet Pazarlaması. Ankara: Detay Yayıncılık.

- $\mathrm{Ku}$ and Fan (2009). Knowledge Sharing and Customer Relationship Management in the Travel Service Alliances, Vol. (20), No. (12).

- Küçükergin, K. G. (2012). Müşteri Sadakatinin Oluşum Sürecine Müşteri Tatmini ve Ataletin Etkisi: Yiyecek- İçecek İşletmelerine Yönelik Bir Uygulama. (Yayımlanmamış Yüksek Lisans Tezi). 
Gazi Üniversitesi Eğitim Bilimleri Enstitüsü Turizm İşletmeciliği Ĕgitimi Anabilim Dalı, Ankara.

- Lau, C., Kwek, L., and Tan, P. (2011). Airline E-ticketing Service: How E-service Quality and Customer Satisfaction Impacted Purchase Intentions, International Business Management, Vol. (5), No. (4), pp. 200-208.

- Li, M., Qiu, S. (C), \& Liu, Z. (2016). The Chinese Way of Response to Hospitality Service Failure: The Effects of Face and Guanxi, International Journal of Hospitality Management, 57: 18-29.

- Meysam, J., and Ghasemali, B. (2016). Evaluating the Effects of Customers Service Quality in International Airlines (case study of Mahan Airline International Flights Passengers), International Journal of Humanities and Cultural Studies.

- Nameghi, E.N.M. (2013a). The Influence of Perceived Image on Passengers' Expectation toward In-flight Hospitality of National Carriers, Doctor of Philosophy Thesis, Graduate School of Business, University Kebangsaan Malaysia.

- Negi, R. (2009). Determining Customer Satisfaction Through Perceived Service Quality: A Study of Ethiopian Mobile Users, International Journal of Mobile Marketing; Vol.4, Number 1; p.31-38.

- Nguyen, N. (2006). The Collective Impact of Service Workers and Service Scape on the Corporate Image Formation. International Journal of Hospitality Management, 25, 227-244.

- Parasuraman, A., Berry, L., and Zeithaml, V. (1998). SERVQUAL: A Multiple-Item Scale For Measuring Consumer Perceptions of Service Quality, Journal of Retailing, Vol. (64), No.(1), pp. 12-40.

- Parasuraman, A., Zeithaml, V., and Berry, L. (1985). A Conceptual Model of Service Quality and its Implications for Future Research, Journal of Hospitality \& Leisure marketing, Vol. 3, pp.5.

- Rhoades, L., and Waguespack, B. (2008). Twenty Years of Service Quality Performance in the US Airline Industry, Managing Service Quality, Vol. 18 No. 1, pp. 20-33.

- Rutkowska, E. and Czarniecka-Skubina, E. (2015). Catering Services in Poland and in Selected Countries, Szczecin University Scientific Journal, No. (872). Service Management, 15 (1).

- Saravanan, R. and Rao, K. (2007). Measurement of Service Quality from the Customer's Perspective - An Empirical Study", Total Quality Management, Vol. (18). No.(4), p.435-449.

- Sezgin, A. C. and Özkaya, F.D. (2014). Toplu Beslenme Sistemlerine Genel Bir Bakış, Akademik Gıda, 12(1), 124-128. 
- Shanka, M. (2012). Measuring Service Quality in Ethiopian Airlines" Journal of Educational and Social Research, Vol. (2), No. (9).

- Statista (the statistics portal) (2018). Annual Growth in Global Air Traffic Passenger Demand from 2005 to 2018", available online http://www. statista.com, (Accessed on 10 April 2018).

- Suess, C. and Mody, M. (2017). Hospitality Health capes: A Conjoint Analysis Approach to Understanding Patient Responses to Hotel Like Hospital Rooms, International Journal of Hospitality Management, 61: 59-72.

- Sultan, C., and Simpson, M. (2000). International Service Variants: Airline Passenger Expectations and Perceptions of Service Quality, Journal of Service Marketing, Vol. (14), No. (3), pp. 188216.

- Teng, C.C. and Chang, J.H. (2013). Mechanism of Customer Value in Restaurant Consumption: Employee Hospitality and Entertainment Cues as Boundary Conditions, International Journal of Hospitality Management, 32, 169-178.

- Thai V.V. (2015). The Impact of Port Service Quality on Customer Satisfaction?: The Case of Singapore, Maritime Economics and Logistics, (June 2015), pp. 1-23. doi:10.1057/mel.2015.19.

- Tsaur, S.H., Chang, T.Y. and Yen, C.H. (2002). The Evaluation of Airline Service Quality by Fuzzy MCDM, Tourism Management, 23/ 107-115.

- Wicks, M., and Roethlein, J. (2009). A Satisfaction-Based Definition of Quality", Journal of Business \&Economic Studies, Vol. 15, No. 1, pp. 82-97.

- Zahari, M., Salleh, M., Kamaruddin,M.S.Y. and Katut, M.Z, (2011). İn-Flight Meals, Passenger's Level of Satisfaction and Re-Flying Intention, İnternational Journal of Social, Behavioral, Educational, Business and Industrial Engineering, 5(12), 1982-1989. 


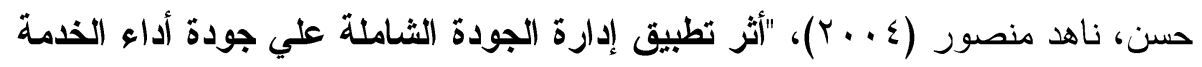

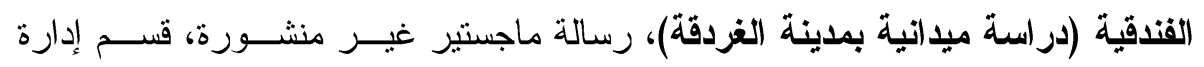

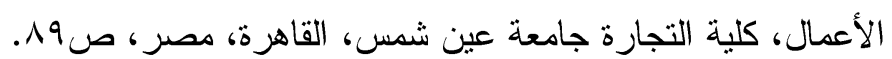

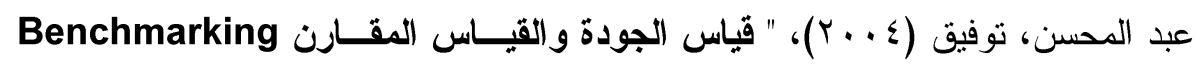

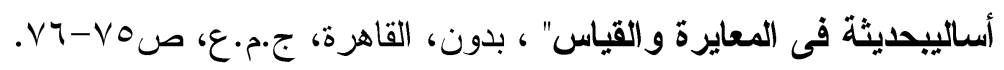

\section{ملخص البحث باللفة العربية}

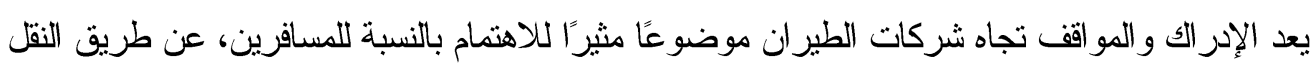

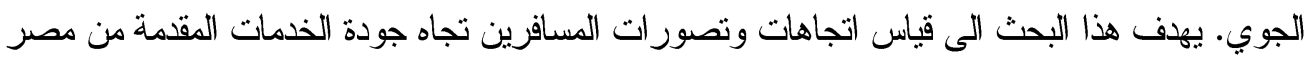
للطيران للخطوط الجوية باستخدام مقياس الرضا. ولتحقيق ذلك ، نم الاعتماد على استخدام المنهج

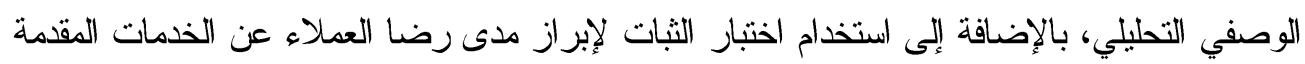

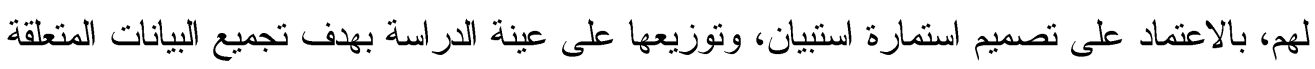

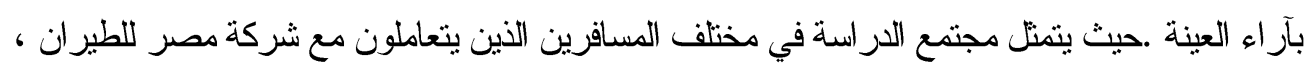

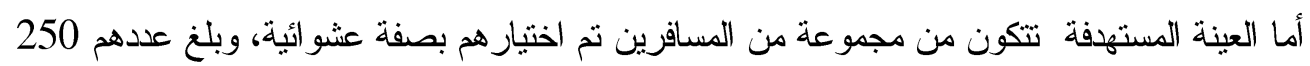

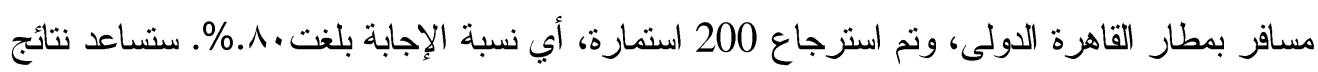
هذا البحث شركة مصر للطيران للخطوط الجوية على إعادة تحديد إستراتيجيتها التسويقية لإستراتيجية تركز على المسافرين وتؤكد على جودة خدمات مصر للطيران للخطوط الجوية. وقد أوصى هذا البحث

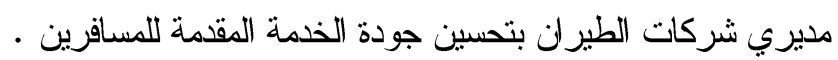
الكلمات المفتاحية: المواقف ، الإدر الك ، جودة الخدمة ، قياس الرضين ، الريا ، مصر للطير ان للخطوط

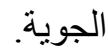

